\title{
APPROACHES GOING TO DETERMINATION PERIODS OF THE HUMAN FACTOR OF NAVIGATORS DURING SUPERNUMERARY SITUATIONS
}

Nosov P. S. - PhD, Associate Professor of the chair Navigation and Electronic Navigation Systems Department, Kherson State Maritime Academy, Ukraine.

Ben A. P. - PhD, Associate Professor, Deputy Rector for scientific and pedagogical work, Head of the Navigation and Electronic Navigation Systems Department, Kherson State Maritime Academy, Ukraine.

Safonova A. F. - PhD, Associate Professor of the Kherson Polytechnic College, Ukraine.

Palamarchuk I. V. - Ms. Sc., Postgraduate student of the Kherson State Maritime Academy, Ukraine.

\section{ABSTRACT}

Context. The problem of identifying the manifestation of the human factor in the context of utility in maritime transport during emergency situations is considered. The aim of the study is to increase safety in maritime transport by identifying positive and negative human factors, as well as analyzing the behavioral reactions affecting the vessel's passage parameters.

Objective. The aim of the work is to determine the approaches and the construction of software tools to identify periods of manifestation of the human factor of the navigators during abnormal situations.

Method. The study identified the types of manifestations of the human factor in the form of intuitive (illogical) behavior of the navigator. The dependence of intuitive behavior, as a reaction, on exceeding the detection threshold of perception of service information, is given. It was determined that the distribution of information load among members of the navigation watch will significantly reduce the detection threshold of the navigator at the time of making management decisions.

It was established that the detection step is to determine the balance of information effects on the navigator and his individual polar reactions. The cycle of updating the navigator model is determined by analyzing his individual behavior model of previous intellectual activity. A formal description of the space of alternatives and reactions of the navigator in the form of polar groups at the moment of vessel management is proposed. Software has been developed that allows the analysis of the vessel's passage trajectory for collision detection and the identification of periods of occurrence of the detection threshold of the navigator.

Analysis of the trajectories made it possible to conclude that before the collision the navigator was in active/passive polar states of action, which directly proportional to the speed of the vessel, which confirms the main hypothesis of the study. As a mathematical tool for solving the problem of classifying individual reactions of the navigator, the factor analysis and a training sample are offered - more than nine typical situations, which make it possible to adequately determine polar reactions according to the principle of utility.

Results. In order to confirm the adequacy of the proposed formal-logical approaches, an experiment was conducted using the Trainer Professional 5000 navigation simulator (NTPRO 5000). The results of the experiment, as well as the developed software, made it possible to identify the time periods of the negative human factor manifestation of the navigator caused by the information overload and to determine its individual stimulus factors. At the same time, the moment of occurrence of an extraordinary situation was determined by analyzing the passage trajectory of the vessel by means of processing log files by passing the Bosporus strait location.

In addition, an algorithm was developed for the formation of the navigator's model and its updating on the basis of individual periods of the negative manifestation of the human factor. The features of the occurrence of informational imbalance between members of the navigation watch in the event of an emergency situation and features of its identification during the passage of the vessel are considered. The obtained results will allow at a qualitatively new level to approach the analysis of the problem of the influence of human factor on the adequate managerial decisions of the navigator.

Conclusions. The proposed formal approaches and the developed software will allow identifying the transition from the controlled adequate state of the navigator to the uncontrolled state with intuitive reactions. The scientific novelty consists in the fact that the developed algorithm of forming a navigator model in a discrete time, which allows to identify its polar reactions during extraordinary situations. The practical significance lies in the fact that the results of the experiment allowed identifying the time periods of the manifestation of the negative human factor of the navigator, caused by the information overload and identifying its individual factors-incentives. Prospects for further research may be the development of software in the form of an expert system defining deviations from a given course during the sea passage, as well as inadequate reactions in the performance of classical maneuvers in case of divergence of ships in constrained areas.

KEYWORDS: human factor, navigator model, detection threshold, emergency situations

\section{ABBREVIATIONS}

NTPRO 5000 navigation simulator "Navi-Trainer Professional 5000";

DSS decision support system;

DT detection threshold;

IS information system.

\section{NOMENCLATURE}

$X_{i}$ is a some sets of alternatives for the interaction of DSS with a navigator; $i$ is the individual index of the navigator;

$I$ is the navigation watch;

$n$ is a members of watch;

$\Theta_{i}$ is a binary relations, are interpreted, as the strengths and weaknesses of the $i$-th navigator;

$R_{+}^{l}$ is the positive orthant of the Euclidean space;

$l$ is the number of factors;

$B$ is the set of admissible distributions;

$\Omega$ is a fixed set of factors; 
$t_{i}(x)$ is a bipolar utility function representing;

$Q_{i}$ is a preference of the $i$-th navigator;

$u_{i}$ is a utility function;

$\gamma_{i}$ is a certain threshold DT;

$\theta$ is a not random parameter of the classification criterion;

$U$ is a monotonic function in time for both classes;

$\rho$ is the distances between the elements;

$\mathbb{R}^{1}$ is the linear normalized spaces of real numbers;

$Z p$ is the registration point of the response;

$\mathbf{P}$ is a certain probability;

$G_{1}, G_{2}$ is a two regions for dividing the entire space;

$C$ is a losses in the classification;

$\mathbf{N}$ is the sample size;

$V$ is the residual component;

$M$ is a correction factor;

$T^{*}$ is a signal of the system;

$\{F\}$ is a space with a certain probability $\mathbf{P}$.

\section{INTRODUCTION}

Practice shows that the readiness status of navigator to make management decisions is described by two interdependent areas - some allowable distribution of influencing factors and warning signals of the DSS. It also takes into account the usefulness of the navigator when making decisions in certain situations. The warning signals of the information system of decision support are formed in such a way as to level the threats posed by relatively most influenced factors of navigators.

This article investigate human factor, namely the moment of transition from the conscious condition of the navigator to the intuitive state, individual factors affecting this process, as well as the analysis of the human factor of the navigator for the usefulness of its actions.

The object of the study is the process of identifying manifestations of the human factor in marine transport.

The subject of the study is a model and information system for reducing the time of identification of the negative impact of the human factor in the management of the vessel.

The purpose of the study is to determine the approaches and construction of software tools, to identify the periods of manifestation of the human factor of navigators during extraordinary situations.

\section{PROBLEM STATEMENT}

It is known that the moment of transition to an intuitive state depends on the intensity of incoming information factors and their nature, after that an DT occurs. This DT leads to the navigator moving to intuitive, unconscious actions. The task of the DSS to not disturb the balance of distribution of the information between members of the navigation watch, using tools both for tracking incoming signals and forecasting possible emergency situations (Fig. 1).

(C) Nosov P. S., Ben A. P., Safonova A. F., Palamarchuk I. V., 2019 DOI 10.15588/1607-3274-2019-2-15

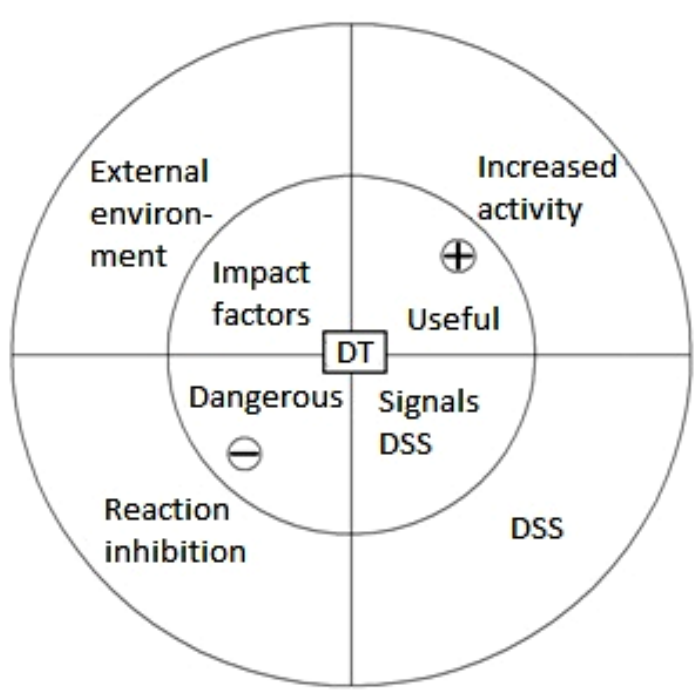

Figure 1 - The balance of information effects on the navigator

The external environment maximizes the utility of members of the navigation watch. If, in a certain condition, the captain and/or members of the navigation watch are meet with DT, the usefulness of actions can be increased by IS due to the redistribution of information factors.

The functions of DSS are summarized as there is no complete conviction about how the situation will develop in the near-threshold area of transition to the intuitive state, therefore this approach method requires a repeatedly experiment.

This will make it possible to clarify the individual causal relationships which lead navigators into the danger zone.

Therefore, it is necessary to solve a number of the following tasks:

1. To determine the dependence of intuitive behavior, as a reaction, on exceeding the detection threshold of perception of official information. Develop an algorithm for the formation of the navigator model, which will allow determining the time of occurrence of reactions leading the navigators in the danger zone.

2. To determine in analytical form an individual set of parameters of the navigator $x=\left(x_{i}\right) \in X$ and his critical information load $x_{i}=\left(x^{1}, \ldots, x^{l}\right)$ in the form of factors $l$ for the purpose of distribution among members of the navigation watch $I=\{1,2, \ldots, n\}$ when an emergency situation occurs.

3. Identify the moment of imbalance $x \in B$ on the basis of comparing the preferences of the navigator $\Theta_{i}$ and the resulting bipolar utility function $t_{i}(x)$, which will allow to determine the non-random distributions $x=\left(x_{i}\right) \in B$ that allow to classify the situation.

4. To determine the cycle of updating the navigator's model $i \in I$ by analyzing his individual behavior model in the form of thresholds $\left\{\gamma_{i}\right\}$ and reactions $X_{i} \subset R_{+}^{l}$. 
5. Develop software that allows analyzing the vessel's passage trajectory for collision detection and identifying the time range of occurrence of the navigator's detection threshold.

6. To conduct an experiment, as well as processing of data from $\log$ files on the executive route planning and passage of the Bosporus strait location using the NTPRO 5000 navigation simulator, in order to classify different behaviors of the navigator.

7. Determine the formal approaches to classifying polar individual reactions of the navigator according to the principle of utility.

Thus, the implementation of the proposed tasks will allow build an information system for identifying the detection threshold of the navigator, which will significantly reduce the negative effects of the human factor on maritime transport.

\section{LITERATURE REVIEW}

Many well-known sources cite various studies related to the negative manifestation of the human factor in maritime transport $[1,2,15]$.

However, many approaches give recommendations that do not allow to accurately identify the moment of the navigator's transition to a stressful state, from logically justified actions to difficult-to-control [9-11]. At the same time, the relationship between the large information flow and the navigator's fatigue leading to catastrophic situations $[4,7]$ is clearly defined.

In the course of investigations into many accidents, the authors note that there are a large number of causes of the negative manifestation of the human factor that are difficult to prevent $[3,5,8,12]$.

However, with the advent of navigation information systems, such as Transas ECDIS, it becomes possible to track the negative behavioral patterns of the navigator at an early stage. The use of formal approaches $[6,13]$, as well as object-oriented programming, will allow a scientific search to be brought closer in a given direction.

\section{MATERIALS AND METHODS}

To determine the algorithm for finding the most successful reactions, it is expediently to apply a modernized cycle of forming a user model in the process of dialogue interaction (Fig. 2).

The peculiarity of the model formation is that initially it is necessary to set the basic information about the navigator in a formal-logical view, where the most preferable of the possible models for representing knowledge's in terms of artificial intelligence [3]. This information allows forming the knowledge's about complex, nature and intensity of factors affecting each separate navigator to DT. In addition, it is important to track the polarity of intuitive behavior in each of the individual cases in order to predict and prevent possible catastrophes due to the human factor.

Imagine this situation in formal form.

Let $X_{i}$ be some sets of alternatives for the interaction of DSS with a navigator, $i$ is the individual index of the navigator who is part of the navigation watch
$I=\{1,2, \ldots, n\}$ consisting of $n$ members. On each set of $X_{i}$, DSS identified binary relations $\Theta_{i}$ are interpreted, as the strengths and weaknesses of the $i$-th navigator, according to which the DSS compares different alternatives from $X_{i}$. If, $X_{i} \subset R_{+}^{l}$ where $R_{+}^{l}$ is the positive orthant of the Euclidean space of dimension $l$, if $l$ is the number of factors, then $x_{i} \in X_{i}$ is the vector consisting of the set $x_{i}=\left(x^{1}, \ldots, x^{l}\right)$ of information flows that the $i$-th navigator receives.

The set of vectors $x=\left(x_{i}\right) \in X$, where $X=\prod_{i \in I} X_{i}$ is the product of the sets $X_{i}$ is called the distribution in group $I$. In this case, the set of admissible distributions will be described with the help of some set $B \subset X$. Then, let

$$
B=\left\{x \in X \mid \sum_{i=1}^{l} x_{i} \leq \Omega\right\}
$$

the set of all redistributions, the total stock of which does not exceed a certain fixed set of factors $\Omega \in R_{+}^{l}$

Suppose that when an imbalance $x \in B$ is detected, the $i$-th navigator meet with some DT, which can be expressed by a real number $t_{i}(x)$. It can be assumed that each $i$-th navigator has a preference $Q_{i}$ on the set of admissible states $B$, which allows the DSS to compare different states $x, x \in B$ from the point of view of its individual information perception, and $t_{i}(x)$ is a bipolar utility function representing $Q_{i}$. Thus, there is a utility function $u_{i}\left(x_{i}\right)$ for the preference $\Theta_{i}$ to determine on $X_{i}$.

Consider situation when, based on the analysis of the model of an individual navigator $i \in I$, the DSS measure the differentiation of the utility of a certain distribution $x=\left(x_{i}\right) \in B$ using an individual measure of DT, such that:

$$
t_{i}(x)=\sum_{j \in I} \max \left\lfloor u_{i}\left(x_{j}\right)-u_{i}\left(x_{i}\right), 0\right\rfloor
$$

The task of the DSS to determine for each navigator $i \in I$ a certain threshold DT $\gamma_{i}, 0 \leq \gamma_{i} \leq 1$. The set of thresholds DT, $\left\{\gamma_{i}\right\}=\gamma$ is interpreted as a set of priorities that are assigned to DSS [14].

Thus, the sequence of actions of the DSS is closed into a loop with each iteration of which the navigator's model is updated and, as a consequence, the change in the threshold of its DT (Fig. 3).

From the above it is clear that the intellectual analysis of the incoming information to the navigator, who makes management decisions at the time of keeping the navigation watch, is possible if to monitor data from all onboard instruments and sensors in real time.

Under the conditions of training practice, it becomes possible to process such data according to a number of criteria that are generated on the server of the NTPRO 5000 (Fig. 4). 


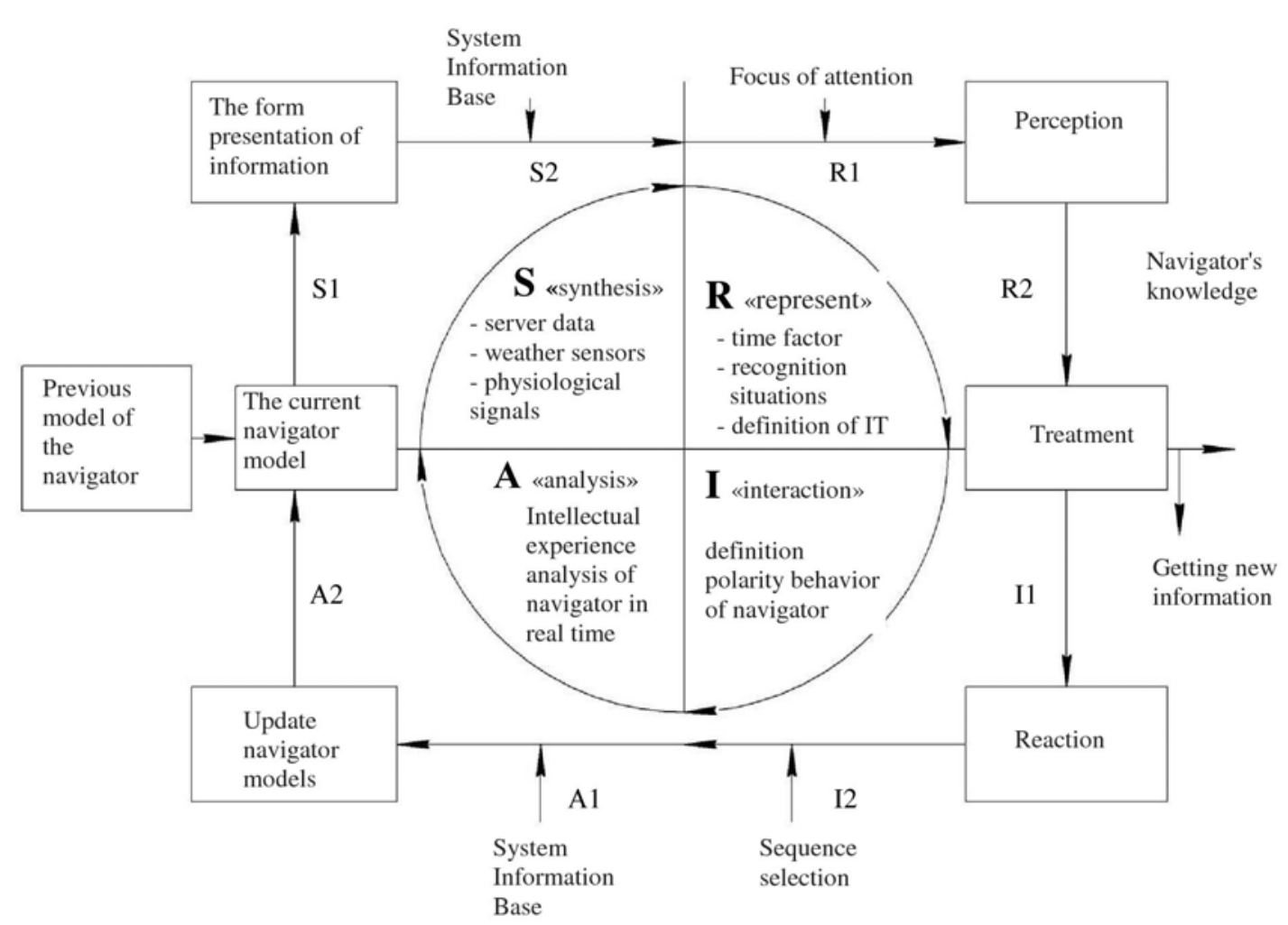

Figure 2 - Algorithm of navigator model formation at discrete-time

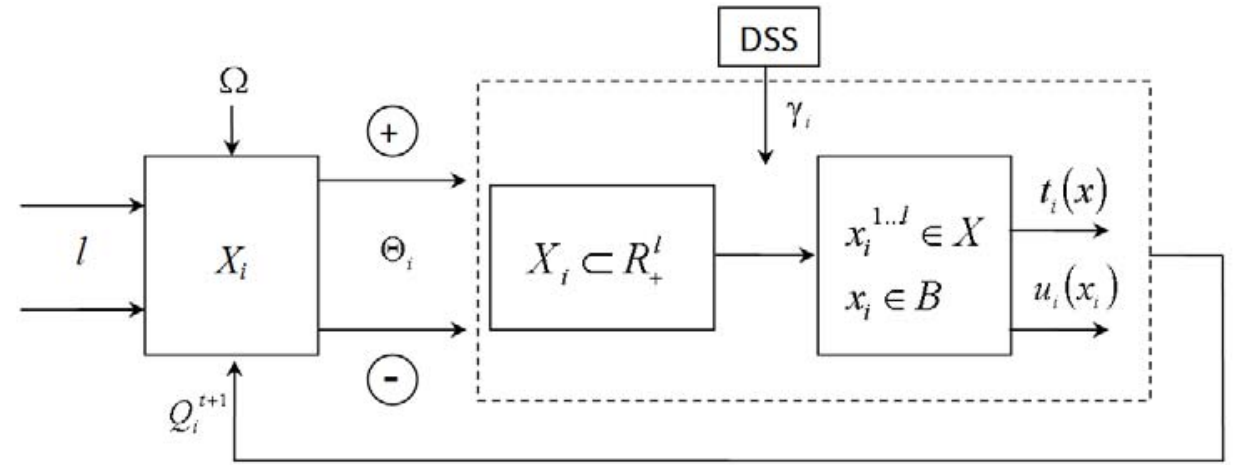

Figure 3 - The cycle of updating the navigator model, taking into account the DT

The task of the DSS to find the threshold of the DT as a period of intellectual behavior of the navigator and the detection of dangerous actions (inactions) leading to disastrous consequences.

In order to convert the server data into a free, relational database management system MySQL, the software and the Microsoft Excel format were developed using the following algorithm (Fig. 5). This software also allows analysis of vessel collision detection in the process of simulator training.

The data analysis after conversion is aimed at detecting both - collisions and the classification of polar reactions caused by the intuitive forms of the human factor demonstration in maritime transport.

The task is complicated by the fact that the classification criterion is established and not available for direct measurement by the random parameter $\theta$ of the influence function on the studied situation.
In connection with the indicated complexity, an algorithm is proposed for solving this problem on the basis of a priori data on classes of features that are not available for direct measurement (indirect evidence).

Considering that the solution of the classification problem involves the application of a mathematical model of the studied erratic system, it is required to evaluate the truth of the conclusion obtained on the basis of experimental data.

One of the typical tasks of classification is to determine the affiliation of the intuitive behavior of the navigator in conditions to one of the polar groups. Thus, the group with the "+" sign is responsible for overactive, spontaneous reactions and the group with the "-" sign, for the absence of reactions due to the sharp inhibition of the nervous system. The polar groups of the navigator arise as reactions to the stressful situation caused by the information overload during the execution of complex maneuvers. 


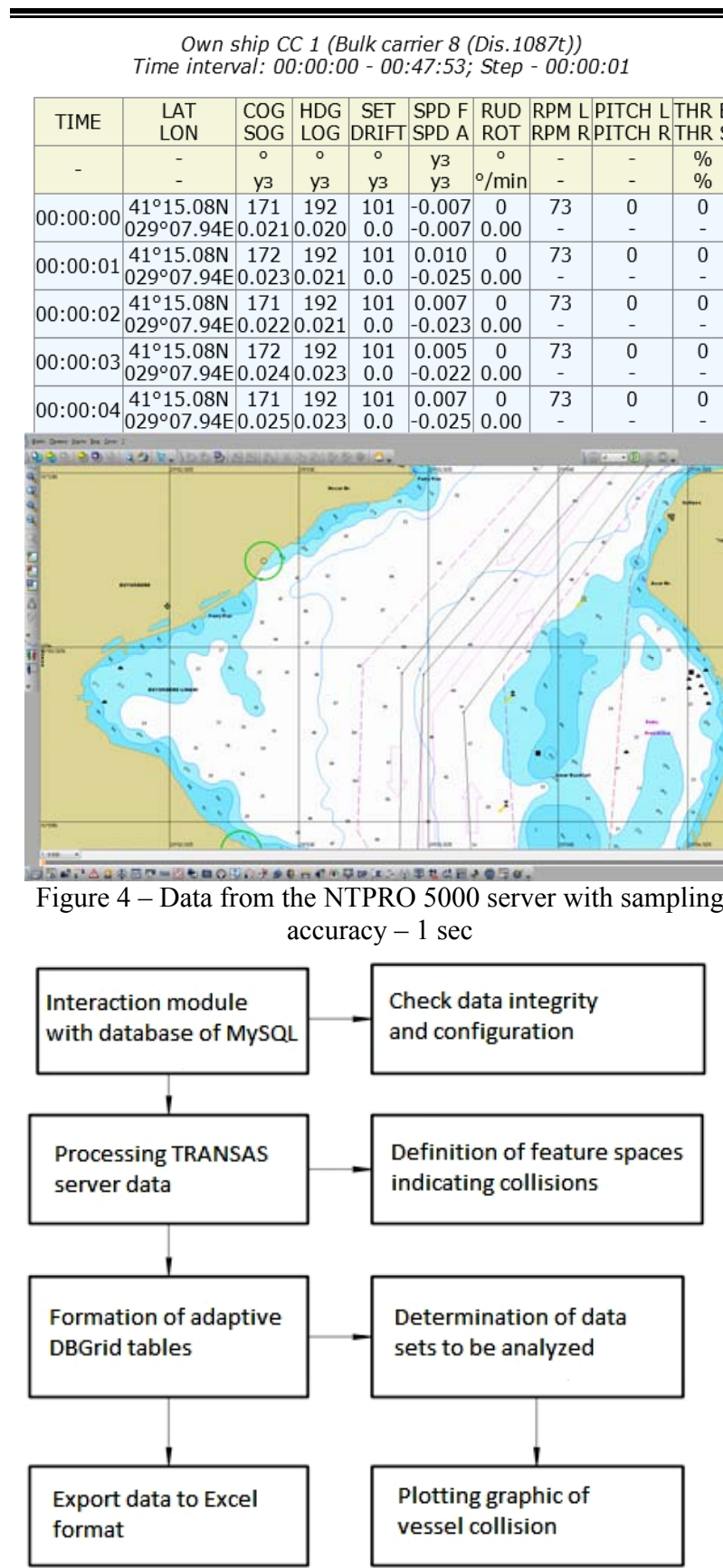

Figure 5 - Algorithm for converting and analyzing server data

\section{EXPERIMENTS}

In the course of the experiment and automated data processing of log files for passage planning and passing the Bosporus Strait location on the NTPRO 5000 simulator, the following graphs were found indicating various behavioral patterns of the navigator (Fig. 6-8a-c).

So using the approaches of automated expert assessment based on the analysis of the trajectory of the vessel's speed, we can conclude that the situation most often manifests itself when the navigator noticed an obstacle, but did not cope with control (Fig. 6a) or did not notice an obstacle at all (Fig. 7a). The smooth passage of the location characterizes the graph presented in Fig. 8a. The developed software also records the collision in time, latitude and longitude, allowing collecting statistics of the most dangerous areas during the passage of the location (Fig. 6-8 b-c).
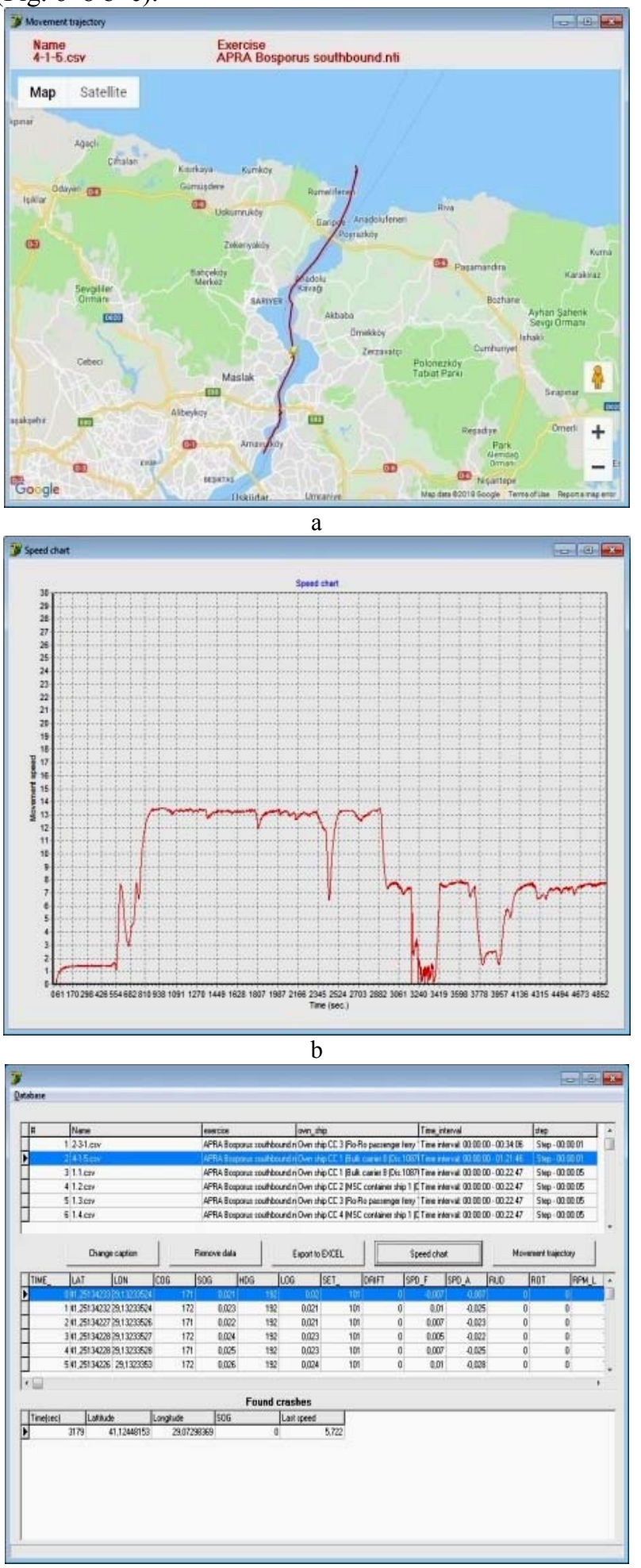

Figure 6 - The vessel's collision with one objects (stable speed): a - navigator noticed an obstacle, but did not cope with control; $\mathrm{b}$ - graph of vessel speed when an obstacle is detected; $\mathrm{c}$ vessel collision identification databasebut loss of control 
e-ISSN 1607-3274 Радіоелектроніка, інформатика, управління. 2019. № 2 p-ISSN 2313-688X Radio Electronics, Computer Science, Control. 2019. №
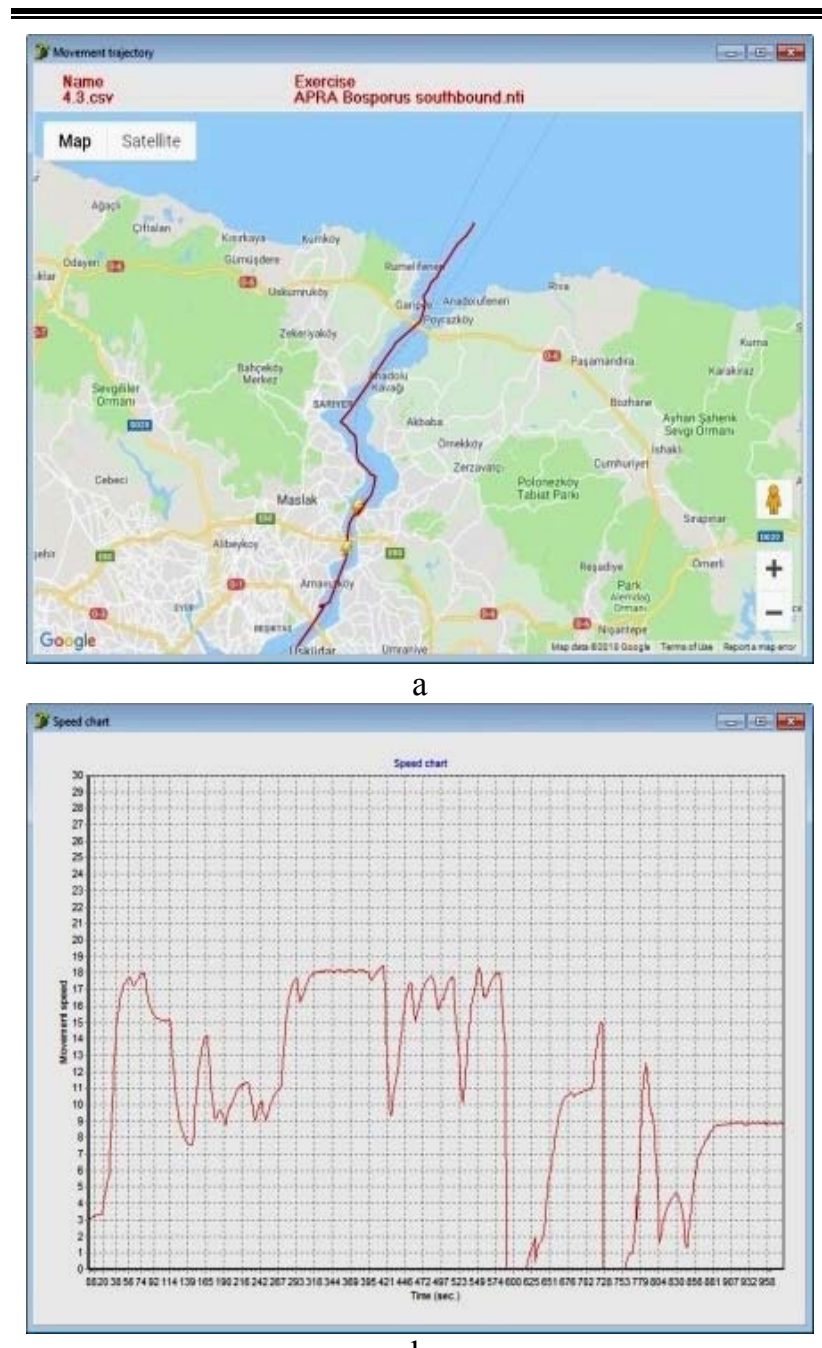

b

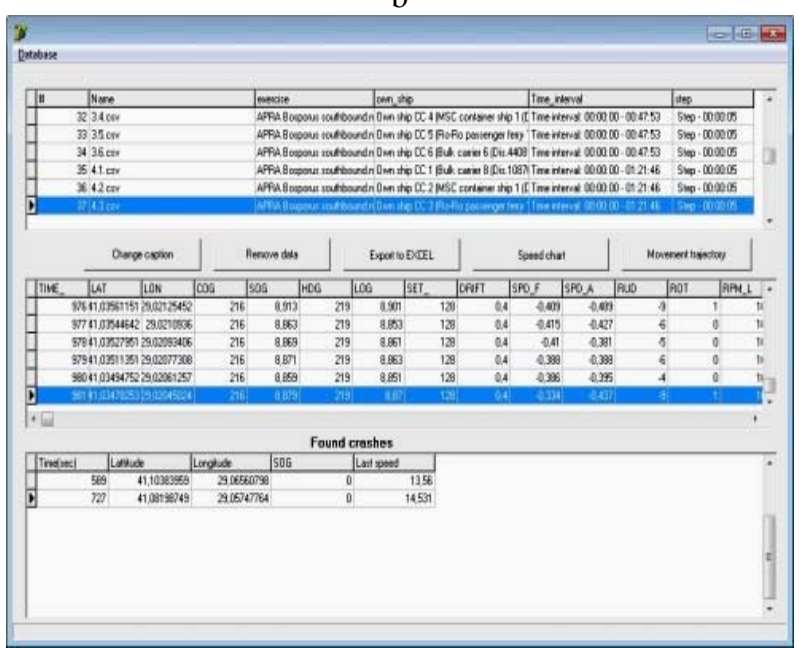

Figure 7 - The vessel's collision with two objects (non stable speed):

$\mathrm{a}$ - navigator did not notice an obstacle at all; $\mathrm{b}$ - vessel speed chart at the time of loss attention; $\mathrm{c}$ - double collision identification database
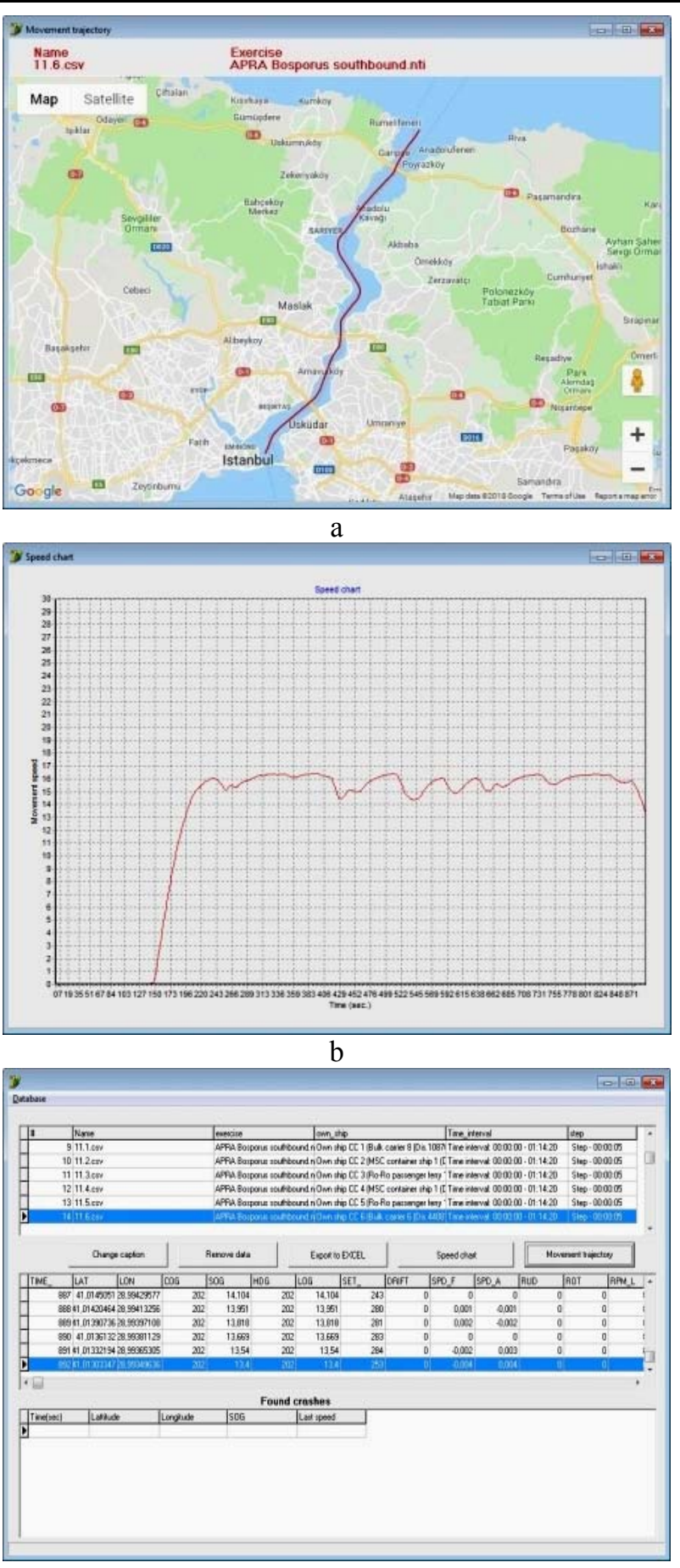

Figure 8 - No vessel's collision:

$\mathrm{a}$ - navigator smooths passage of the location; $\mathrm{b}$ - smooth vessel speed chart; $\mathrm{c}-$ non collision identification database

Let's describe each case:

At trial exercise Fig. 6 all looks that navigator feels uncertain but with not much influence of stress and situation almost always looks under control.

Long time navigator proceeds with very slow speed around 1.5 knots $(0-554 \mathrm{sec})$. After that rapidly and often change speed till $810 \mathrm{sec}$. 
From $810 \mathrm{sec}$ till $2345 \mathrm{sec}$ and from $2524 \mathrm{sec}$ till 2882 sec vessel passage mostly stable (except between $2345-$ $2524 \mathrm{sec}$ where vessel speed down twice - from 13.0 knots till 6.5 knots). From $2882 \mathrm{sec}$ navigator met circumstances which brought to extremely speed reduction till 5.722 knots and finally to collision at 3179 sec. After vessel collision the trial passage has been continue but behavior and actions of navigator was very uncertain till the end of exercise. As we can see the navigator detect obstruct in time but did not react properly at this dangerous situation.

At trial exercise Fig. 7 we can see that navigator show himself as certain and much bolded due to all time wish proceed with high vessel speed 17.0-18.0 knots (which is much over maximum acceptable at Bosporus passage) and very often speed and courses alteration. Such kind of high speed brought till often major speed reductions as final till vessel collisions at $589 \mathrm{sec}$ (speed $13.56 \mathrm{knots}$ ) and at $727 \mathrm{sec}$ (speed 14.531 knots). After collisions the trial passage continues again with same navigator behavior. In this particular case navigator even did not determine risk of collision due to vessel high speed and bolded behavior. When analyzing the trajectory presented in Fig. 7, it can be concluded that the navigator (bridge team) was unsure of their actions, and as a result, the speed and courses of the vessel changed, indicating an increased stress situation on the bridge.

At trial exercise Fig. 8 navigator show himself as certain considering the average passage speed was around 16.0 knts which is over maximum acceptable at Bosporus Strait. However all the time trial passage was stable and looks stress free with some speed deviation due to vessel courses alteration.

\section{RESULTS}

Into comparing all trial exercises need to say that best results shown when certain behavior of navigator has background as good knowledge's and experience which can be achieved by using of DSS also. The lowest speed did not guaranty safe passage but gives more time to determine obstruct and take final and right decision but not bring vessel into safe navigation due to it is group of different factors to avoid and prevent collision.

When solving the problem of classification, temporary indicators of the activity of the navigator at the workplace, the direction of sight and movement along the bridge in situations requiring certain behavioral patterns can serve as an immeasurable classification feature $\theta$.

In the general case, it can be stated that the behavior of the navigator during a stressful situation is described by a random sequence $\theta(t)$, which makes it possible to apply the discriminant analysis method. Consequently, there is a one-dimensional probability distribution density $f(\theta)$, where $\theta$ the non-random function and does not depend on $t$.

In order to solve the problem, it is necessary to determine the value of the classification sign and compare them with the values corresponding to the standards of the studied polar classes.

This article defines the values of the information load on the navigator and, the result of which changes in response to information factors (arousal or inhibition). The construction of a mathematical model is based on the formal connection of the function $\theta$ and the information load $u$. Next, it is necessary to solve the model classification problem using the data of a computational experiment. It should be noted that as an input function of the studied system will be considered a stationary random sequence $\theta(t)$, with the $U(\theta, T)$ - corresponding function of the system response to the impact.

To solve the model classification problem, we will consider $\theta$ and $U$ as elements of the metric spaces $\{X\}$ and $\{F\}$, accordingly, with the distances between the elements $\quad \rho_{\{X\}}\left(\theta_{1}, \theta_{2}\right), \quad \rho_{\{F\}}\left(U_{1}, U_{2}\right), \quad \theta_{1}$, $\theta_{2} \in\{X\}, U_{1}, U_{2} \in\{F\}$. The spaces $\{X\}$ and $\{F\}$ are linear normalized spaces $\mathbb{R}^{1}$ of real numbers i.e.

$$
\begin{gathered}
\rho_{\{F\}}\left(U_{1}, U_{2}\right)=\left\|U_{2}-U_{1}\right\|= \\
\left|U_{2}-U_{1}\right|, \rho\{X\}\left(\theta_{1}, \theta_{2}\right)=\left\|\theta_{2}-\theta_{1}\right\| .
\end{gathered}
$$

At the same time, the condition of the correctness of the task of distinguishing values $\theta$ by the known values of $U$ corresponding to them is identical to the condition of the correctness of the task of finding a "solution" $\theta$ from the known "initial data" $U$ :

$$
\theta=F U
$$

if the conditions are met that the range of values of the set $\{\theta\}$ will always lie on one side of the registration point $Z p$ of the response, and the time of registration of the signal $T^{*}$ is selected on the interval, where $U$ is a monotonic function in time for both classes. Then the following conditions must be met: the mapping $\{\theta\} \rightarrow\{U\}$, where $\{\theta\} \subset\{X\},\{U\} \subset\{F\} ;\{\theta\}$ - domain of definition, a limited set on the numerical line IR ${ }^{1}$.

At this stage, the problem of classification is solved in space $\{F\}$ with a certain probability $\mathbf{P}$. The choice of a classification rule is reduced to choosing a method for dividing the entire space of possible values of $U$ into two regions $G_{1}$ and $G_{2}$. But there are losses in the classification, and they are equal to $\mathrm{C}(1 / 2)$ and $\mathrm{C}(2 / 1)$. These losses can be large and not satisfy the researcher.

To increase the likelihood of correct classification, apply the method factor analysis. A prerequisite for the application of this method is the fact that $U_{1}, U_{2}, \ldots, U_{N}$, where $\mathbf{N}$ is the sample size, are elements of the same population. The mathematical expectation as a numerical characteristic of this distribution, which does not vary with time, is a common factor for a sample of $U_{1}, U_{2}, \ldots$, $U_{\mathrm{N}}$. Then any value of $U$ can be represented as $U=\mathbf{M} U+V$, where $V$ is the residual component,

$$
\mathbf{M} U_{1} \int_{G_{1}} U_{\rho_{1}}(U) d U \text { for class } 1 \text {, }
$$




$$
\begin{gathered}
\int_{G_{2}} \rho_{1}(U) d U=1, \\
\mathbf{M} U_{2} \int_{G_{2}} U_{\rho_{2}}(U) d U \text { for class } 2, \\
\int_{G_{2}} \rho_{2}(U) d U=1,
\end{gathered}
$$

where $\rho_{1}(U)=G f_{1}(U), \rho_{2}(U)=G f 2_{1}(U), G=(d U / d \theta)^{1 / 2}$ is the Jacobian transformation for the probability density at the transition $\{\theta\}$ to $\{U\}$.

If $\mathbf{M} U_{1} \neq \mathbf{M} U_{2}$, then, having determined the values of common factors for both classes, it is possible with $\mathbf{P}=100 \%$ to talk about which class the observed factors $U_{1}, U_{2}, \ldots, U_{\mathrm{N}}$ belong to. Thus, as a result of the application of factor analysis, we solve the problem of classification by a sign $\mathrm{M} U$ in space $\{F\}$ with probability $\mathbf{P}=100 \%$ for $N \rightarrow \infty$.

Thus, if in the space $\{X\}$ the classification problem is solved with probability $\mathbf{P}$, then the problem of classification in space $\{F\}$ is solved with the same probability $\mathbf{P}$. True and inverse statement.

Based on this corollary, it can be argued that the classification problem can be solved on the basis of $\mathrm{MU}$ and in the space $\{X\}$ with the same probability $\mathbf{P}=100 \%$ for $N \rightarrow \infty$. Turning to the mathematical expectation as a more informative classification feature, we minimize the losses in the classification: $C(1 / 2)=C(2 / 1)=0$. But in practice we get an empirical average. The point estimate of the mathematics expectation value for large $N(N \geq 10)$ will be calculated by the formula: $\langle U\rangle=\frac{1}{N} \sum_{i=1}^{N} U_{1}$.

Thus, the proposed formal classification mechanism by the most significant classification parameter is adequate and supported by experimental data. An important step in the preliminary modeling is the accurate diagnosis of the stimulus factors "including" one of the two polar reactions of navigator's at the time of a stressful situation.

\section{DISCUSSION}

Experimental data give reason to believe that there is a division into two polar classes of behavior of navigators. That confirms the feasibility of the study and the developed software application.

Analysis of the execution of the route planning and the direct passage by many navigation watch crews among the cadet staff by means of the NTPRO 5000 training center at the KSMA showed that the behaviors model of the navigators differ depending on their individual perception of input information.

Experience shows that the skills and behavioral patterns developed during training practice are inherited during real passages in unfamiliar locations. The developed approaches, classification mechanisms and software have been introduced into the work of the KSMA training center in order to develop optimal behavioral models of navigators during emergency situations, which will prevent the negative manifestations of the human factor in real conditions.

The basic principles and research were discussed at the 10th International scientific and practical conference Modern Information and Innovation Technologies in Transport MINTT-2018 [16].

The introduction of software will allow quickly and efficiently process large amounts of data and highlight the classification signs of the negative manifestation of the human factor, both among cadets and experienced seafarers during traineeships and advanced training in accordance with the standards of IMO and STCW 78/85. In the future, further research is planned to develop software, in the form of an expert system that determines deviations from a given course during the passage, as well as inadequate reactions when performing classical maneuvers when vessels diverge in constrained areas.

\section{CONCLUSIONS}

The results of the experiment using the NTPRO 5000, as well as the developed software, allow identifying the time periods of manifestation of the negative human factor of the navigator. The identification is based on the definition of information overload and as a result of imbalance. For the unification of the identification process, an algorithm was developed for forming the navigator model and updating it.

The solved task, which consists in the construction of a model and software for identifying periods of occurrence of the detection threshold of a navigator during extraordinary situations and allows to significantly increase safety in marine transport.

The scientific novelty consists in the fact that the developed algorithm of forming a navigator model in a discrete time, which allows to identify its polar reactions during extraordinary situations. The algorithm takes into account the recursive updating of the model and differs from the existing by taking into account the detection threshold of the navigator.

The practical significance lies in the fact that the results of the experiment, as well as the developed software, allowed identifying the time periods of the manifestation of the negative human factor of the navigator, caused by the information overload and identifying its individual factors-incentives. At the same time, the moment of the occur of a emergence situation was determined by analyzing the navigation trajectory of the vessel by means of processing log-files of the server on the passage of the location "Bosphorus", "Dardanell" and others.

Prospects for further research will be aimed at building the classification of sets of navigator reactions at the time of their performing maneuvers and operations which leading to negative manifestations of the human factor in conditions of information overload. 


\section{ACKNOWLEDGEMENTS}

The work is carried out within the framework of "Creation of high-accuracy intellectual systems for military-oriented and commercial ship's navigation" (state registration number 0117U002176), of navigation and ECDIS departments of Kherson State Maritime Academy Navigation Faculty (scientific adviser: PhD Associate Professor, Deputy Rector for scientific and pedagogical work, Head of the Navigation and Electronic Navigation Systems Department, Kherson State Maritime Academy, Ukraine, Ben A. P.).

\section{REFERENCES}

1. Ben' A. P. Lyuds'kiy faktor $\mathrm{v}$ avtomatizovanikh sistemakh upravlinnya sudnom ta shlyakhi znizhennya yogo vplivu. Naukoviy visnik Khersonskoy derzhavnoy morskoy akademii, 2012, 2(7). pp. 26-30 (in Ukrainian).

2. Kosenko Y. I., Roslyakova S. V., \& Nosov P. S. Sistema identifikatsii funktsional'noi entropii sub'ekta kritichnoi infrastrukturi. Zbirnik nauchnykh trudov po materialam mizhnarodnoi naukovoi praktichnoi konferencii «Sovremennye napravleniya teoreticheskikh i prikladnykh issledovaniy», Tekhnicheskie nauki, 2013, 8, pp. 50-54 (in Ukrainian).

3. Xi Y. T., Yang Z. L., Fang Q. G., Chen W. J., \& Wang J. A new hybrid approach to human error probability quantification-applications in maritime operations, Ocean Engineering, 2017, Vol. 138, pp. 45-54 doi:10.1016/j.oceaneng.2017.04.018.

4. Arslan O., \& Er I. D. Effects of Fatigue on Navigation Officers and SWOT Analyze for Reducing Fatigue Related Human Errors on Board TransNav, The International Journal on Marine Navigation and Safety of Sea Transportation, 2007, Vol. 1, No. 3, pp. 345-349.

5. Dixena D., Chakraborty B., \& Debnath N. Application of Case-Based Reasoning for Ship turning Emergency to prevent Collision, 9th IEEE International Conference on Industrial Informatics INDIN, 2011.

6. Jech T. Set theory. Berlin, Heidelberg, New York, Barcelona, Budapest, Hong Kong, London, Milan, Paris, Santa Clara, Singapore, Tokyo, Springer, 1997. DOI: 10.1007/3-540-44761-X.

7. Özdemir Ü., \& Güneroğlu A. Strategic approach model for investigating the cause of maritime accidents, Promet -
Traffic - Traffico, Karadeniz Technical University, 2015, 27(2), pp. 113-123. DOI: 10.7307 / ptt.v27i2.1461.

8. Carotenuto A., Angiola M. F., Ivana M., Sibilio F., Saturnino A., Traini E., \& Amenta F. The Psychological General Well-Being Index (PGWBI) for assessing stress of seafarers on board merchant ships, International Maritime Health, 2013, 64(4), pp. 215-220. DOI: 10.5603/IMH.2013.0007.

9. Yang C., Gao J., Du J., Wang H. Y., Jiang J. X., \& Wang Z. G. Understanding the outcome in the chinese changjiang disaster in 2015: a retrospective study, Journal of emergency medicine, 2017, 2(52), pp. 197-204. DOI: 10.1016/ j.jemermed. 2016.08.013.

10. Zhang L., Lu J., \& Ai Y. Analyzing human error in maritime transportation in China based on game theory, Journal of Wuhan University of Technology (Transportation Science and Engineering), 2014, 38(6), pp. 1282-1290. DOI: 10.3963/j.issn.2095-3844. 2014. 06.022.

11. Berg H. P. Human Factors and Safety Culture in Maritime Safety, The International Journal on Marine Navigation and Safety of Sea Transportation, 2013, 7(3), pp. 343-352. DOI: 10.12716/1001.07.03.04.

12. Guidance notes on safety culture and leading indicators of safety. American Bureau of Shipping (ABS), Houston, 2012, $74 \mathrm{p}$.

13. Corović B. Research of Marine Accidents through the Prism of Human Factors, Promet Traffic \& Transportation, 2013, Vol. 25, No. 4, pp. 369-377. DOI: 10.7307/ ptt.v25i4.1210.

14. Jech T. Set theory. Berlin, Heidelberg, New York, Barcelona, Budapest, Hong Kong, London, Milan, Paris, Santa Clara, Singapore, Tokyo, Springer, 1997. DOI: 10.1007/3-540-44761-X. (in English).

15. Hyun C. L., \& Poong H. S. A computational model for evaluating the effects of attention, memory, and mental models on situation assessment of nuclear power plant operators, Reliability Engineering \& System Safety, 2009, Vol. 94, Issue 11, pp. 1796-1805. DOI: 10.1016/ j.ress.2009.05.012.

16. Nosov P. S., Ben A. P., \& Safonov M. S. Model construction of individual scenarios for the elimination of the human factor, Suchasni infonmaciyni ta innovaciyni tehnologii na transposti, MINTT-2018: Materialy X Miznarodnoi naukovo-praktichnoyi konferencii, 29-31 May 2018, pp. 224-225 (in Ukrainian).

Received 16.10.2018. Accepted 27.12.2018

УДК 004.942:316.454.54

\section{ПІДХОДИ ДО ВИЗНАЧЕННЯ ПЕРІОДІВ ПРОЯВУ ЛЮДСЬКОГО ФАКТОРА СУДНОВОДІЇВ ПІД ЧАС ПОЗАШТАТНИХ СИТУАЦЙ}

Носов П. С. - канд. техн. наук, доцент, доцент кафедри судноводіння та електронних навігаційних систем Херсонська державна морська академія, Україна.

Бень А. П. - канд. техн. наук, доцент, заступник ректора 3 науково-педагогічної роботи, завідувач кафедри судноводіння та електронних навігаційних систем, Херсонська державна морська академія, Україна.

Сафонова А. Ф. - канд. техн. наук, доцент, Херсонський політехнічний коледж, Україна.

Паламарчук І. В. - капітан далекого плавання, аспірант, Херсонська державна морська академія, Україна.

\section{АНОТАЦЯ}

Актуальність. Розглядається проблема ідентифікації проявів людського фактору у контексті корисності на морському транспорті під час позаштатних ситуацій. Метою дослідження є підвищення безпеки на морському транспорті засобами ідентифікації позитивного і негативного людського фактора, а також аналізу поведінкових реакцій що впливають на параметри переходу судна.

Мета. Метою роботи є визначення підходів і побудови програмних засобів, для ідентифікації періодів прояву людського фактора судноводіїв під час позаштатних ситуацій.

Метод. В рамках дослідження визначені види прояву людського фактора у формі інтуїтивної (нелогічної) поведінки судноводія. Наводиться залежність інтуїтивної поведінки, як реакції, що залежить від перевищення інформаційного порогу 
сприйняття службової інформації. Визначено, що розподіл інформаційного навантаження між членами вахтової служби істотно знизить інформаційний поріг судноводія в момент прийняття управлінських рішень. Встановлено, що етапом ідентифікації є визначення балансу інформаційних впливів на судноводія і його індивідуальних полярних реакцій. Визначено цикл поновлення моделі судноводія за допомогою аналізу його індивідуальної моделі поведінки попередньої інтелектуальної діяльності. Запропоновано формальний опис простору альтернатив і реакцій судноводія у вигляді полярних груп в момент управління судном. Розроблено програмне забезпечення, що дозволяє виконувати аналіз траєкторії управління судном на предмет виявлення зіткнень і ідентифікувати періоди виникнення інформаційного порогу судноводія. Аналіз траєкторій, дозволив зробити висновок, що судноводій перед зіткненням знаходився в полярних на предмет активності станах активний / пасивний, що прямо-пропорційно відбивалося на швидкості ходу судна, що підтверджує основну гіпотезу дослідження. У якості математичного апарату для розв'язання задачі класифікації індивідуальних реакцій судноводія запропоновано факторний аналіз і навчальна вибірка - більш ніж дев'ять типових ситуацій, що дозволяе адекватно визначати полярні реакції за принципом корисності.

Результати. 3 метою підтвердження адекватності запропонованих формально-логічних підходів був проведений експеримент із застосуванням навігаційного тренажера Trainer Professional 5000 (NTPRO 5000). Результати експерименту, а також розроблене програмне забезпечення дозволили ідентифікувати тимчасові періоди прояву негативного людського фактора судноводія, викликані інформаційним перевантаженням і визначити його індивідуальні фактори-стимули. При цьому, момент виникнення позаштатної ситуації визначався шляхом аналізу траєкторії управління судном засобами обробки $\log$-файлів серверу по проходженню локації «Босфор».

Крім того, був розроблений алгоритм формування моделі судноводія і ії поновлення на основі індивідуальних періодів негативного прояву людського фактора. Розглянуто особливості виникнення інформаційного дисбалансу між членами вахтової служби при виникненні позаштатної ситуації і особливостей його ідентифікації під час переходу судна. Наведені результати дозволять на якісно новому рівні підійти до аналізу проблеми впливу людського фактора на адекватні управлінські рішення судноводія.

Висновки. Запропоновані формальні підходи дозволять ідентифікувати перехід від контрольованого адекватного стану судноводія до неконтрольованого стану з інтуїтивними реакціями. Наукова новизна полягає в тому, що вперше розроблений алгоритм формування моделі судноводія у дискретному часі, що дозволяє ідентифікувати його полярні реакції під час позаштатних ситуацій. Практична цінність полягає у результатах експерименту, що дозволили ідентифікувати часові періоди прояву негативного людського фактора судноводія. Перспективами подальших досліджень може бути розробка програмного забезпечення у вигляді експертної системи для визначення відхилень від заданого курсу під час переходу, а також неадекватних реакцій при здійсненні класичних маневрів при розбіжності судів в обмежених районах.

КЛЮЧОВІ СЛОВА: людський фактор, модель судноводія, інформаційний поріг, позаштатні ситуації.

\section{УДК 004.942:316.454.54}

\section{ПОДХОДЫ К ОПРЕДЕЛЕНИЮ ПЕРИОДОВ ПРОЯВЛЕНИЯ ЧЕЛОВЕЧЕСКОГО ФАКТОРА СУДОВОДИТЕЛЕЙ ВО ВРЕМЯ ВНЕШТАТНЫХ СИТУАЦИЙ}

Носов П. С. - канд. техн. наук, доцент, доцент кафедры судовождения и электронных навигационных систем Херсонская государственная морская академия, Украина.

Бень А. П. - канд. техн. наук, доцент, заместитель ректора по научно-педагогической работе, заведующий кафедрой судовождения и электронных навигационных систем, Херсонская государственная морская академия, Украина

Сафонова А. Ф. - канд. техн. наук, доцент, Херсонский политехнический колледж, Украина.

Паламарчук И. В. - капитан дальнего плавания, аспирант, Херсонская государственная морская академия, Украина.

\section{АННОТАЦИЯ}

Актуальность. Рассматривается проблема идентификации проявления человеческого фактора в контексте полезности на морском транспорте во время внештатных ситуаций. Целью исследования является повышение безопасности на морском транспорте посредствам идентификации позитивного и негативного человеческого фактора, а также анализа поведенческих реакций влияющих на параметры перехода судна.

Цель. Целью работы является определение подходов и построение программных средств, для идентификации периодов проявления человеческого фактора судоводителей во время внештатных ситуаций.

Метод. В рамках исследования определены виды проявления человеческого фактора в форме интуитивного (нелогичного) поведения судоводителя. Приводится зависимость интуитивного поведения, как реакции, от превышения информационного порога восприятия служебной информации. Определено, что распределение информационной нагрузки между членами вахтенной службы существенно снизит информационный порог судоводителя в момент принятия управленческих решений. Установлено, что этапом идентификации является определение баланса информационных воздействий на судоводителя и его индивидуальных полярных реакций. Определен цикл обновления модели судоводителя посредством анализа его индивидуальной модели поведения предшествующей интеллектуальной деятельности. Предложено формальное описание пространства альтернатив и реакций судоводителя в виде полярных групп в момент управления судном. Разработано программное обеспечение, позволяющее выполнять анализ траектории управления судном на предмет обнаружения столкновений и идентифицировать периоды возникновения информационного порога судоводителя. Анализ траекторий, позволил сделать вывод, что судоводитель перед столкновением находился в полярных на предмет активности состояниях активен/пассивен, что прямо-пропорционально отражалось на скорости хода судна, что подтверждает основную гипотезу исследования. В качестве математического аппарата для решения задачи классификации индивидуальных реакций судоводителя предложен факторный анализ и обучающая выборка - более чем девять типовых ситуаций, позволяющая адекватно определять полярные реакции по принципу полезности. 
Результаты. С целью подтверждения адекватности предложенных формально-логических подходов был проведен эксперимент с применением навигационного тренажера Trainer Professional 5000 (NTPRO 5000). Результаты эксперимента, а также разработанное программное обеспечение позволили идентифицировать временные периоды проявления негативного человеческого фактора судоводителя, вызванные информационным перегрузом и определить его индивидуальные факторыстимулы. При этом, момент возникновения внештатной ситуации определялся путем анализ траектории управления судном посредствам обработки $\log$-файлов по прохождению локации «Босфор».

Кроме того был разработан алгоритм формирования модели судоводителя и ее обновления на основе индивидуальных периодов негативного проявления человеческого фактора. Рассмотрены особенности возникновения информационного дисбаланса между членами вахтенной службы при возникновении внештатной ситуации и особенностей его идентификации во время перехода судна. Приведенные результаты позволят на качественно новом уровне подойти к анализу проблемы влияния человеческого фактора на адекватные управленческие решения судоводителя.

Выводы. Предложенные формальные подходы позволят идентифицировать переход от контролируемого адекватного состояния судоводителя к неконтролируемому состоянию с интуитивными реакциями. Научная новизна заключается в том, что впервые разработан алгоритм формирования модели судоводителя в дискретном времени, что позволяет идентифицировать его полярные реакции во время внештатных ситуаций. Практическая ценность заключается в результатах эксперимента, котрые позволили идентифицировать временные периоды проявления негативного человеческого фактора судоводителя. Перспективами дальнейших исследований может быть разработка программного обеспечения в виде экспертной системы определяющей отклонения от заданного курса во время перехода, а также неадекватных реакций при совершении классических маневров при расхождении судов в стесненных районах.

КЛЮЧЕВЫЕ СЛОВА: человеческий фактор, модель судоводителя, информационный порог, внештатные ситуации.

\section{ЛІТЕРАТУРА / ЛИТЕРАТУРА}

1. Бень А. П. Людський фактор в автоматизованих системах управління судном та шляхи зниження його впливу / А. П. Бень // Науковий вісник Херсонської державної морської академії. - 2012. - № 2 (7). - С. 2630.

2. Косенко Ю. І. Система ідентифікації функціональної ентропії суб'єкта критичної інфраструктури / Ю. І. Косенко, С. В. Рослякова, П. С. Носов // Сб. научных трудов по матер. МНПК «Современные направления теоретических и прикладных исследований». - Технические науки. - Одесса : КУПРИЕНКО. - 2013. - Том 8. - С. 50-54.

3. A new hybrid approach to human error probability quantification-applications in maritime operations / [Y. T. Xi, Z. L. Yang, Q. G. Fang et al] // Ocean Engineering. - 2017. - Vol. 138. - P. 45-54. DOI: 10.1016/j.oceaneng.2017.04.018.

4. Arslan O. Effects of Fatigue on Navigation Officers and SWOT Analyze for Reducing Fatigue Related Human Errors on Board TransNav / O. Arslan, I. D. Er // The International Journal on Marine Navigation and Safety of Sea Transportation. - 2007. - Vol. 1, Number 3. September. - P. 345-349.

5. Dixena D. Application of Case-Based Reasoning for Ship turning Emergency to prevent Collision / D. Dixena, B. Chakraborty, N. Debnath // 9th IEEE International Conference on Industrial Informatics INDIN. - Lisbon: IEEE - 2011. ISSN: 1935-4576.

6. Jech T. Set theory / T. Jech // Corr. ed. - Berlin; Heidelberg; New York; Barcelona; Budapest; Hong Kong; London; Milan; Paris; Santa Clara; Singapore; Tokyo; Springer, 1997, P. 243. DOI: 10.1007/3-540-44761-X.

7. Özdemir Ü. Strategic approach model for investigating the cause of maritime accidents / Ü. Özdemir, A. Güneroğlu // Promet - Traffic - Traffico, 2015, Volume 27, Issue 2. Karadeniz Technical University. - P. 113-123. DOI: $10.7307 /$ ptt.v27i2.1461.

8. Carotenuto, A. The Psychological General Well-Being Index (PGWBI) for assessing stress of seafarers on board merchant ships / [A. Carotenuto, M. F. Angiola, M. Ivana et al.] // International Maritime Health. - 2013. - Vol. 64(4). P. 215-220. DOI: 10.5603/IMH.2013.0007.

9. Yang C. Understanding the outcome in the chinese changiiang disaster in 2015: a retrospective study / [C. Yang, J. Gao, J. Du et al] // Journal of emergency medicine. - 2017. - № 2 (52) - NY. : Elsevier science Inc, P. 197-204. DOI: 10.1016/j.jemermed.2016.08.013.

10. Zhang L. Analyzing human error in maritime transportation in China based on game theory / L. Zhang, J. Lu, Y. Ai // Journal of Wuhan University of Technology (Transportation Science and Engineering). - 2014. - Volume 38, Issue 6. Dalian : Dalian Maritime University. - P. 1282-1290. DOI: 10.3963/j.issn.2095-3844.2014.06.022.

11. Berg H. P. Human Factors and Safety Culture in Maritime Safety / H. P. Berg // The International Journal on Marine Navigation and Safety of Sea Transportation, Vol. 7 , Number $3 \quad$, 2013. pp. 343-352. DOI: $10.12716 / 1001.07 .03 .04$.

12. Guidance notes on safety culture and leading indicators of safety. - [Effective from 01.01.2012]. - Houston: American Bureau of Shipping (ABS), 2012. $-74 \mathrm{p}$.

13. Corović B. Research of Marine Accidents through the Prism of Human Factors / B. Corović, P. Djurovic // Promet Traffic \& Transportation. - 2013. - Vol. 25, No. 4. - P. 369-377.

14. Jech T. Set theory / T. Jech // Corr. ed. - Berlin; Heidelberg; New York; Barcelona; Budapest; Hong Kong; London; Milan; Paris; Santa Clara; Singapore; Tokyo; Springer, 1997. - P. 243. DOI: $10.1007 / 3-540-44761-X$.

15. Hyun C. L. A computational model for evaluating the effects of attention, memory, and mental models on situation assessment of nuclear power plant operators / C. L. Hyun, H. S. Poong // Reliability Engineering \& System Safety, 2009. - Vol. 94, Issue 11. - P. 1796-1805. DOI: 10.1016/j.ress.2009.05.012.

16. Nosov P. S. Model construction of individual scenarios for the elimination of the human factor / P. S. Nosov, A. P. Ben, M. S. Safonov // Сучасні інформаційні та інноваційні технології на транспорті, MINTT-2018: Матеріали X Міжнародної науково-практичної конференції, 2931 травня. - Херсон, 2018. - С. 224-225. 